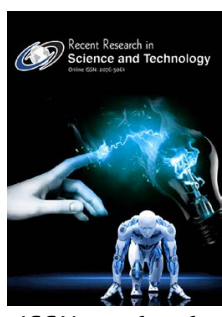

ISSN: 2076-5061

\title{
Neglected Tropical Diseases (NTDs) - A Snapshot of Research
}

\author{
Partha Paul', Dipu Podder², Arup Kumar33, Md. Ataur Rahman', \\ Md. Hajbiur Rahman', Nafisa Habib Purba4, Md. Zahid Al Hasan', \\ Tabassum Akter ${ }^{5 *}$
}

'Department of Microbiology, Noakhali Science and Technology University, Sonapur, Noakhali-3814, Bangladesh, ${ }^{2}$ Bangladesh Food Safety Authority (BFSA), Probashi Kalyan Bhaban, 71-72. Eskaton Garden, Dhaka-1000, Bangladesh, ${ }^{3}$ Materials Science Division, Atomic Energy Centre, 4-Kazi Nazrul Islam Avenue, Shahbag, Dhaka-1000, Bangladesh, ${ }^{4}$ Outreach Supervisor (Nutritionist), Society for Health Extension and Development (SHED), Cox's Bazar-4700, Bangladesh, ${ }^{5}$ Department of Pharmacy, Noakhali Science and Technology University, Sonapur, Noakhali-3814, Bangladesh

\section{ABSTRACT}

More than a billion people-one-sixth of the earth's population is infected with one or more neglected tropical diseases (NTDs) in developing countries. Over the past decade, interests in NTDs have resurged as these are a barrier to achieving broader human development outcomes (e.g., improved newborn, child and maternal health, food, and nutritional safety). Several national and international organizations (such as the WHO, USAID, CDC, and others) concentrate on NTDs and fighting to control or prevent them. This review describes a brief introduction to NTDs, the global burden of the diseases in terms of disability-adjusted life years (DALYs), years lived with disability (YLDs) and years of life lost (YLLs). This paper also reviews the negative impact of these diseases on global economies and discusses strategies for public health to prevent and eliminate these diseases, the achievements and challenges that can be achieved to address adversity there.

*Corresponding Author:

Tabassum Akter

E-mail: tabassum.pharma.

nstu@gmail.com

KEYWORDS: neglected tropical diseases, ascariasis, trichuriasis, schistosomiasis, lymphatic filariasis (LF)

\section{INTRODUCTION}

NTDs are diseases that affect many subtropical and tropical regions, such as Asia, Africa, and the Americas, where the most impoverished people live. According to a World Bank study, 51 percent of the people of sub-Saharan Africa (SSA), a prime focus for NTDs, lives on less than US $\$ 1.25$ a day, and $73 \%$ of the people lives on less than US $\$ 2$ a day (Chen \& Ravallion, 2008). In relation to their outcome on health, NTDs lead to an immense economic and social burden arising from physical disabilities, loss of social status, social stigma, discrimination, blindness, disfigurement, growth failure, malnutrition, and impaired cognitive development. Such interrelated outcomes perpetuate the cycle of poverty by stopping people from leading productive lives and influencing households, communities, and countries as a whole negatively.

In the 2010 study, NTDs responsible for 26.06 million disabilityadjusted life years (DALYs) (95 percent confidence interval: $20.30,35.12$ ), i.e., years of healthy life lost due to disability or premature life (Hotez et al., 2014). The DALY metric quantifies the burden of a disease as the number of healthy years of life lost to morbidity and mortality and is an internationally recognized summary measure of population health. It facilitates comparing the relative impact of diseases and risk factors over time (Devleesschauwer et al., 2014, Murray \& Acharya, 1997). NTDs are also referred to as disablers rather than killers, and that's why DALY metric is used as it has a direct co-relationship with morbidity rather than mortality. The biodiversity of NTDs indicates that the strategies for control or elimination are also very diverse. Several NTDs can be managed by drug treatment (preventive chemotherapy), on a nation or community scale, via mass drug administration (MDA) campaigns. Other NTDs require different control or elimination approaches and strategies, including specialized drugs and/or vector control (limiting or eradicating insects (pathogens transmitting flies and bugs) (Molyneux, 2013). Despite a range of strategies, several organizations, including the World Bank, Bill \& Belinda Gates Foundation, United Kingdom Department for International Development, pharmaceutical companies, and government officials from donor and endemic countries chat together at an event entitled "Uniting to Combat NTDs: Ending the Neglect

Copyright: (-) The authors. This article is open access and licensed under the terms of the Creative Commons Attribution License (http://creativecommons.org/licenses/by/4.0/) which permits unrestricted, use, distribution and reproduction in any medium, or format for any purpose, even commercially provided the work is properly cited. Attribution - You must give appropriate credit, provide a link to the license, and indicate if changes were made. 
and Reaching the 2020 Goals", and set targeted goals for NTDs (Molyneux, 2012).

\section{EPIDEMIOLOGY AND GLOBAL BURDEN SCENARIO}

NTDs are biologically diverse, so they are found in regions with favorable conditions, such as poor hygienic conditions and sanitation. It is reckoned that 1.6 billion people worldwide are affected by NTDs, and 149 countries are endemic for at least one NTD (The Lancet Global Health, 2020). Bacteria, viruses, protozoa, and helminth parasites are the infectious agents responsible for NTDs. These agents are transmitted primarily through various vectors (flies, mosquitoes, sandflies, blackflies, etc.) and may cause NTDs when these vectors contact individuals. The major NTDs, their causative agents, and endemic regions are mentioned in table l (Hossain et al., 2017).

The Global Burden of Disease (GBD) study launched in 1990 as a single World Bank-commissioned analysis, now known as the GBD project, quantified the health impacts of more than 100 diseases and injuries for eight regions of the world, providing estimates of morbidity and mortality by region, age, and sex. NTDs are among the world's most familiar conditions, with over 2 billion cases, according to the 2013 GBD study (Table 2).

Since 1990, GBD 2013 shows some important and noteworthy changes in the incidence or prevalence of these diseases. The most remarkable is a 610 percent rise in the incidence of dengue fever, consistent with the extensive occurrence of this disease in the Americas, Asia, and Africa above what would be predicted due to shifts in population demographics. GBD 2013 showed that in prevalent cases of lymphatic filariasis, onchocerciasis, and vision loss attributable to trachoma, there were substantial reductions (approximately 30\%-40\%) (de Vlas et al., 2016). A $71 \%$ decrease in the number of cases of human African trypanosomiasis (HAT) infection is also included in the study (Steinmann et al., 2015).

The burden of NTD is represented by DALYs lost, which corresponds to the years of healthy life lost due to early death, ill-health or disability. Seventeen NTDs together forming the fourth largest disease burden of all communicable diseases, accounting for almost 46-57 million DALYs lost. When assessed using DALYs, NTDs become second only to HIV/AIDs and before malaria and tuberculosis in DALYs lost (WHO, 2004). Seven of these 17 diseases are the most prevalent and are liable for most of the burden of NTD disease, affecting 1.4 billion people globally. Infections with three soil-transmitted helminth (hookworm, ascariasis, and trichuriasis), lymphatic filariasis, onchocerciasis, trachoma, and schistosomiasis are all seven of these diseases (Norris et al., 2012). This burden is because these 17 neglected diseases are not killers but make people disable, leading them to become a burden on the earth.

The major NTD burden is represented in table 3 by DALYs (Vos et al., 2015; Murray et al., 2015; Abubakar et al., 2015). The years of disability (YLD) and the years of life lost (YLL), the main component of DALYs, are both assessed in this table. For most neglected tropical diseases, YLDs contribute to a higher proportion of disability-adjusted life years than do YLLs, and the most common diseases (see Table 3 ) are also the ones that affect the most disability. In total, 8 million YLLs and 17 million YLDs were liable for NTDs in 2013 (Herricks et al., 2017). The GBD 2013 study compares the variation in DALYs since 2005 (Table 3), and the change in percentage shows the small effort made to reduce the amount of DALYs.

In addition to the NTDs mentioned above, chikungunya has posed a threat to public health in recent years. The burden of chikungunya in India during the 2006 epidemic was calculated to be 25,588 DALYs lost, with a cumulative burden of 45.26 DALYs per a one million-person population (Krishnamoorthy et al., 2009). The estimated total disability-adjusted life years lost for the 2014 Colombian epidemic was 40.44 to 45.14 per 100k population (Cardona-Ospina et al., 2015). However, even DALYs do not reveal the entire story of the adverse consequences of NTDs. Some of the unique and potential shortcomings of Global Burden of Diseases Study 2010 have been outlined elsewhere (Byass et al., 2013). In addition, DALYs only assess direct health loss and, for instance, do not take into account the economic influence of the NTDs that results from adverse effects on child development and school attendance, agriculture (particularly zoonotic NTDs), and overall economic productivity (Miguel et al., 2004; Hotez et al., 2009). Nor do disability-adjusted life years account for specific costs of surveillance, treatment, and prevention measures. Yet, economic influence has risen as an important feature of the neglected tropical diseases, which may trap people in a cycle of poverty and illness (Miguel et al., 2004; Hotez et al., 2009; King, 2010). Additional aspects not taken into account by the DALY metrics are the essential stigmatization components for many of the neglected tropical diseases and the spillover impacts to community and family members (Perera et al., 2007; Weiss, 2008), loss of tourism (Mavalankar et al., 2009), and health system overloads (e.g., during dengue outbreaks). Ultimately, efforts to control and eliminate NTDs could generate economic and social benefits that are not necessarily reflected in the DALY metrics, particularly among the poor communities who are most affected (Hotez et al., 2009).

\section{PUBLIC HEALTH STRATEGIES}

The WHO proposes a mixture of five approaches for the control and prevention of NTDs, which are implemented as per the epidemiology of the specific NTD. Intensified disease management (IDM), preventive chemotherapy (PCT), vector control, hygiene and sanitation, safe water, and public veterinary health are the strategies. The unprecedented decision by some pharmaceutical companies to donate 'as many drugs as needed for as long as needed' to help eradicate NTDs has changed the landscape of NTDs by trying to make the drugs available to the poorest nations, with PCT becoming the most common approach to treating the five major diseases (Samuels \& Pose, 2013).

- PCT includes a single dose of medication once or twice a year, typically given by the distribution of medicines on 
Table 1: List of NTDs, their causative agent (s), and the potential endemic areas of these NTDs (Hossain et al., 2017)

\begin{tabular}{|c|c|c|}
\hline NTDs & Causative agent (s) & Endemic areas \\
\hline \multicolumn{3}{|c|}{ Bacterial infections } \\
\hline Buruli ulcer & Mycobacterium ulcerans & $\begin{array}{l}\text { Australia, Guyana, Malaysia, Mexico, Peru, Sri Lanka, Papua } \\
\text { New Guinea, West, and Central Africa }\end{array}$ \\
\hline Bartonellosis & Bartonella henselae, other Bartonella spp. & Globally distributed \\
\hline Bovine tuberculosis & Mycobacterium bovis & Globally distributed (highest rates in developing countries) \\
\hline Cholera & Vibrio cholerae & $\begin{array}{l}\text { Southern and Central Africa, Dominican Republic, Haiti, } \\
\text { Cambodia, Papua New Guinea, Thailand, Malaysia, Indian } \\
\text { subcontinent }\end{array}$ \\
\hline ETEC infection & Enterotoxigenic Escherichia coli (ETEC) & Globally distributed (highest rates in developing countries) \\
\hline Salmonellosis & $\begin{array}{l}\text { Salmonella enteric serovars, S. enteritidis, S. } \\
\text { typhimurium, S. typhi, S. paratyphi }\end{array}$ & Globally distributed (highest rates in developing countries) \\
\hline Shigellosis & Shigella dysenteriae, S. boydii, S. flexneri, S. sonnei & Globally distributed (highest rates in developing countries) \\
\hline Leprosy & Mycobacterium leprae & $\begin{array}{l}\text { Brazil, China, Mozambique, Myanmar, Madagascar, } \\
\text { Indonesia, India, Nepal, Philippines, Vietnam, Sudan, and } \\
\text { other tropical and subtropical regions }\end{array}$ \\
\hline Leptospirosis & Leptospira interrogans & Globally distributed (highest rates in developing countries) \\
\hline Trachoma & Chlamydia trachomatis & $\begin{array}{l}\text { Africa, Middle East, part of Asia, Australia, Mexico, South } \\
\text { America }\end{array}$ \\
\hline Treponematoses & Treponema pallidum & Globally distributed (highest rates in tropical regions) \\
\hline Relapsing fever & $\begin{array}{r}\text { Borrelia recurrentis, B. duttoni, other Borrelia spp. } \\
\text { Viral infections }\end{array}$ & Africa (highest rates), parts of Americas, Asia, Europe \\
\hline Dengue & Dengue fever virus (genus: Flavivirus) & $\begin{array}{l}\text { Indian subcontinent, South-East Asia, Pacific Islands, Central } \\
\text { and South America, Parts of Africa and Northern Australia }\end{array}$ \\
\hline Yellow fever & Yellow fever virus (genus: Flavivirus) & $\begin{array}{l}\text { South America, West, and Central Africa, occasionally in } \\
\text { East Africa and Central America }\end{array}$ \\
\hline Japanese encephalitis & Japanese encephalitis virus (genus: Flavivirus) & $\begin{array}{l}\text { Indian subcontinent, South-East Asia, intermittently in } \\
\text { Northern Australia, and the Western Pacific }\end{array}$ \\
\hline Chikungunya & Chikungunya virus & $\begin{array}{l}\text { Africa, Southeast Asia, the Indian subcontinent, Pacific } \\
\text { Region, and most probably in the (sub) tropical regions of the } \\
\text { Americas }\end{array}$ \\
\hline Rabies & Rabies virus (genus: Lyssavirus) & Globally distributed \\
\hline Rift Valley fever & Rift Valley fever virus (genus: Phlebovirus) & Africa and Arabian Peninsula \\
\hline \multirow[t]{6}{*}{ Viral haemorrhagic fevers } & $\begin{array}{l}\text { Arenaviridae: Lassa virus, Chapare virus, Guanarito } \\
\text { virus, Junin virus, Machupo virus, Sabia virus }\end{array}$ & $\begin{array}{l}\text { Certain viruses are endemic in certain areas. Lassa virus: } \\
\text { Guinea, Liberia, Nigeria, Sierra Leone }\end{array}$ \\
\hline & $\begin{array}{l}\text { Bunyaviridae: Crimean-Congo haemorrhagic fever } \\
\text { virus (HFV), Hantaviruses, Puumala virus, }\end{array}$ & $\begin{array}{l}\text { Crimean-Congo HFV: Africa, Arabian Peninsula, Bulgaria, } \\
\text { Central Asia, Turkey, South-West Russia }\end{array}$ \\
\hline & Filoviridae: Ebola virus, Marburg virus Flaviviridae: & Hantavirus: Globally distributed; Filoviridae: Angola, Congo, \\
\hline & Omsk HFV, Kyasanur forest disease virus & $\begin{array}{l}\text { Gabon, Kenya, Sudan, Uganda } \\
\text { Omsk HFV: West Siberia }\end{array}$ \\
\hline & & Kyasanur forest disease virus: India \\
\hline & Helminth infections & \\
\hline Dracunculiasis & Dracunculus medinensis & Mali, South Sudan, Ethiopia \\
\hline Cysticercosis/taeniasis & Taenia solium, T. saginata, Diphyllobothrium latum & Globally distributed \\
\hline Enterobiasis & Enterobius vermicularis & Globally distributed (highest rates in developing countries) \\
\hline Echinococcosis & Echinococcus granulosus, E. multilocularis & Globally distributed \\
\hline Intestinal fluke infection & Echinosoma spp. Fasciolopsis buski, Metagonimus spp. & $\begin{array}{l}\text { Bangladesh, India, Malaysia, Indonesia, Taiwan, China, } \\
\text { Philippines, Vietnam, Thailand, Cambodia }\end{array}$ \\
\hline Fascioliasis & Fasciola gigantic, F. hepatica & $\begin{array}{l}\text { Bolivia, Cuba, Chile, Ecuador, Egypt, Iran, France, Portugal, } \\
\text { Peru, Spain }\end{array}$ \\
\hline Clonorchiasis & Clonorchis sinensis & China, South Korea, Taiwan \\
\hline Paragonimiasis & Paragonimus spp. & $\begin{array}{l}\text { India, Pakistan, Nepal, Sri Lanka, Malaysia, Thailand, } \\
\text { Vietnam, Laos, Philippines, Taiwan, China, South Korea, } \\
\text { Japan, Cameroon, Nigeria, Liberia, Costa Rica, Ecuador, } \\
\text { Guinea, Guatemala, Gabon, Peru, Panama, Mexico }\end{array}$ \\
\hline Opisthorchiasis & Opisthorchis felineus, 0 . viverrini & $\begin{array}{l}\text { Thailand, Vietnam, Laos, Ukraine, Siberia, Kazakhstan, } \\
\text { Russia }\end{array}$ \\
\hline Lymphatic filariasis & Wuchereria bancrofti, Brugia malayi, B. timori & Africa, Asia, Central and Southern America \\
\hline Loiasis & Loa loa & Central and West Africa \\
\hline Mansonellosis & Mansonella perstans, M. streptocerca, M. ozzardi & Caribbean, Central and South America, Sub-Saharan Africa \\
\hline Schistosomiasis & $\begin{array}{l}\text { Schistosoma haematobium, S. guineensis, S. } \\
\text { intercalatum, S. japonicum, S. mansoni, S. mekongi }\end{array}$ & $\begin{array}{l}\text { Sub-Saharan Africa, Parts of Central and West Africa, some } \\
\text { Caribbean islands, China, Indonesia, Philippines, Cambodia, } \\
\text { Laos }\end{array}$ \\
\hline Onchocerciasis & Onchocerca volvulus & Africa, a small part of Central and Southern America \\
\hline Ascariasis & Ascaris lumbricoides & Globally distributed \\
\hline Hookworm infection & Ancylostoma duodenale, Necator americanus & Globally distributed \\
\hline Strongyloidiasis & Strongyloides stercoralis & Globally distributed \\
\hline
\end{tabular}


Table 1: (Continued)

\begin{tabular}{|c|c|c|}
\hline NTDs & Causative agent (s) & Endemic areas \\
\hline Trichuriasis & Trichuris trichiura & Globally distributed \\
\hline Toxocariasis & Toxocara canis, T. cati & Globally distributed \\
\hline \multicolumn{3}{|c|}{ Ectoparasitic infections } \\
\hline Scabies & Sarcoptes scabiei & $\begin{array}{l}\text { Globally distributed (highest rates in tropical and subtropical } \\
\text { regions) }\end{array}$ \\
\hline Myiasis & $\begin{array}{l}\text { Parasitic fly larvae (Calliphoridae Oestridae, } \\
\text { Sarcophagidae and others) }\end{array}$ & $\begin{array}{l}\text { Globally distributed (highest rates in tropical and subtropical } \\
\text { regions) }\end{array}$ \\
\hline \multicolumn{3}{|c|}{ Fungal infections } \\
\hline Mycetoma (Madura foot) & $\begin{array}{l}\text { Various fungi (eumycetoma) and } \\
\text { bacteria (actinomycetoma, pseudomycetoma) }\end{array}$ & Africa, India, Central, and South America \\
\hline Paracoccidiomycosis & Paracoccidioides brasiliensis & $\begin{array}{l}\text { Argentina, highest rates in Brazil }(80 \%) \text {, Colombia, Ecuador, } \\
\text { Mexico, parts of Central America, Venezuela }\end{array}$ \\
\hline \multicolumn{3}{|c|}{ Protozoal infections } \\
\hline Chagas disease & Trypanosoma cruzi & Latin America \\
\hline Human African trypanosomiasis & sTrypanosoma brucei gambiense, T. brucei rhodesiense & Africa \\
\hline Amoebiasis & Entamoeba histolytica & Globally distributed (highest rates in developing countries) \\
\hline Giardiasis & Giardia intestinalis & Globally distributed (highest rates in developing countries) \\
\hline Leishmaniasis & $\begin{array}{l}\text { Visceral leishmaniasis: Leishmania donovani, L. chagasi, } \\
\text { L. infantum Mucocutaneous leishmaniasis: L. major, L. } \\
\text { tropica, L. mexicana, L. braziliensis }\end{array}$ & $\begin{array}{l}\text { Indian subcontinent, Asia, Africa, South Africa, } \\
\text { Mediterranean basin }\end{array}$ \\
\hline
\end{tabular}

Table 2: Prevalent cases of NTDs in 2013 and percent change from 1990 to 2013 according to the Global Burden of Disease Study (GBD) 2013 (Vos et al., 2015)

\begin{tabular}{|c|c|c|}
\hline Disease & Prevalent cases (in millions) in 2013 & Percent change since 1990 \\
\hline Ascariasis & 804.4 & $-25.5 \%$ \\
\hline Trichuriasis & 477.4 & $-11.6 \%$ \\
\hline Hookworm & 471.8 & $-5.1 \%$ \\
\hline Schistosomiasis & 290.6 & $30.9 \%$ \\
\hline Foodborne trematodiases & 80.2 & $51.1 \%$ \\
\hline Dengue*t & 58.4 & $610.9 \%$ \\
\hline Lymphatic filariasis & 43.9 & $-32.1 \%$ \\
\hline Onchocerciasis & 17.0 & $-31.2 \%$ \\
\hline Chagas disease & 9.4 & $22.4 \%$ \\
\hline Cutaneous/mucocutaneous leishamaniasis & 3.9 & $174.2 \%$ \\
\hline Trachomat & 2.4 & $-39.2 \%$ \\
\hline Cysticercosist & 1.0 & $-26.3 \%$ \\
\hline Cystic echinococcosist & 0.8 & $-15.4 \%$ \\
\hline Leprosy & 0.7 & $61.3 \%$ \\
\hline Visceral leishmaniasis & 0.1 & $35.1 \%$ \\
\hline Rabies*+ & 0.02 & $-40.4 \%$ \\
\hline African trypanosomiasis & 0.02 & $-71.1 \%$ \\
\hline Other NTDs & 59.7 & $-5.0 \%$ \\
\hline Total cases & 2,322 & NA \\
\hline Additional NTDs & Prevalent cases (in millions) in 2013 & Percent change since 1990 \\
\hline Trichomoniasis & 67.1 & $45.6 \%$ \\
\hline Scabies & 66.1 & $24.8 \%$ \\
\hline Typhoid fever* & 11.0 & $-19.9 \%$ \\
\hline Paratyphoid fever* & 6.4 & $-27.9 \%$ \\
\hline Venomous animal contact* & 5.5 & $-2.7 \%$ \\
\hline Cholera* & 2.3 & $6.1 \%$ \\
\hline Cryptosporidiosis* & 1.4 & $-19.4 \%$ \\
\hline Amoebiasis* & 0.4 & $17.0 \%$ \\
\hline Total cases of additional neglected diseases & 160.2 & NA \\
\hline
\end{tabular}

* Incident cases in 2013 rather than prevalent cases, tsymptomatic cases only.

See GBD 2013 capstone manuscript on prevalence, incidence, and years lived with a disability (YLDs) for detail on percent (\%) change calculations (Vos et al., 2015). All data provided in this table (exception of cholera, rabies, amoebiasis and cryptosporidiosis) are also obtainable on the website of the Institute for Health Indicators and Evaluation (IHME) and have been previously published in Vos et al. (2015). Abbreviations: NA, non-applicable

a wide scale, known as mass drug administration (MDA). Not fewer than $65 \%-80 \%$ of the total population living in endemic areas must take the medication for MDA to be effective. As such, it is oftentimes administered by teachers 
Table 3: Leading causes of disability-adjusted life years (DALYs) resulting from the NTDs according to the Global Burden of Diseases Study (GBD) 2013 with attributing years lived with disability (YLDs) and years of life lost (YLLs) (Vos et al., 2015; Murray et al., 2015; Abubakar et al., 2015)

\begin{tabular}{|c|c|c|c|c|}
\hline NTDs & $\begin{array}{l}\text { DALYs (in millions) in } \\
2013\end{array}$ & $\begin{array}{l}\text { Percent change for } \\
\text { DALYs 2005-2013 }\end{array}$ & $\begin{array}{l}\text { YLDs (in millions) } \\
\text { in } 2013\end{array}$ & $\begin{array}{l}\text { YLLs (in millions) } \\
\text { in } 2013\end{array}$ \\
\hline Visceral leishmaniasis & 4.24 & $8.7 \%$ & 0.008 & 4.23 \\
\hline Foodborne trematodiases & 3.63 & $14.6 \%$ & 3.63 & 0 \\
\hline Schistosomiasis & 3.06 & $-13.9 \%$ & 2.86 & 0.2 \\
\hline Hookworm & 2.18 & $-0.5 \%$ & 2.18 & 0 \\
\hline Lymphatic filariasis & 2.02 & $-14.3 \%$ & 2.02 & 0 \\
\hline Ascariasis & 1.27 & $-29.0 \%$ & 0.93 & 0.34 \\
\hline Rabies & 1.24 & $-14.6 \%$ & 0.0001 & 1.24 \\
\hline Onchocerciasis & 1.18 & $-19.4 \%$ & 1.18 & $0 *$ \\
\hline Dengue & 1.14 & $17.0 \%$ & 0.56 & 0.58 \\
\hline Trichuriasis & 0.58 & $-12.3 \%$ & 0.58 & 0 \\
\hline African trypanosomiasis & 0.39 & $-54.3 \%$ & 0.005 & 0.38 \\
\hline Chagas disease & 0.34 & $4.6 \%$ & 0.10 & 0.24 \\
\hline Cysticercosis & 0.34 & $-16.4 \%$ & 0.31 & 0.03 \\
\hline Cystic echinococcosis & 0.18 & $-14.1 \%$ & 0.08 & 0.1 \\
\hline Trachoma & 0.17 & $-18.1 \%$ & 0.17 & 0 \\
\hline Cutaneous and mucocutaneous leishmaniasis & 0.04 & $35.9 \%$ & 0.04 & 0 \\
\hline Leprosy & 0.04 & $8.6 \%$ & 0.04 & 0 \\
\hline Other NTDs & 3.13 & $-11.8 \%$ & 2.26 & 0.87 \\
\hline Total NTDs & 25.17 & NA & 16.95 & 8.21 \\
\hline Additional neglected diseases & $\begin{array}{l}\text { DALYs (in millions) in } \\
2013\end{array}$ & $\begin{array}{l}\text { Percent change for } \\
\text { DALYs 2005-2013 }\end{array}$ & $\begin{array}{l}\text { YLDs (in millions) } \\
\text { in } 2013\end{array}$ & $\begin{array}{l}\text { YLLs (in millions) } \\
\text { in } 2013\end{array}$ \\
\hline Typhoid fever & 11.13 & $-13.7 \%$ & 0.16 & 10.97 \\
\hline Cholera & 5.17 & -20.1 & 0.04 & 5.13 \\
\hline Paratyphoid fever & 3.82 & $-8.0 \%$ & 0.04 & 3.78 \\
\hline Cryptosporidiosis & 3.46 & -29.6 & 0.19 & 3.27 \\
\hline Venomous animal contact & 3.00 & $-3.4 \%$ & 0.15 & 2.85 \\
\hline Scabies & 1.71 & $4.8 \%$ & 1.71 & 0 \\
\hline Amoebiasis & 0.38 & $-23.8 \%$ & 0.04 & 0.34 \\
\hline Trichomoniasis & 0.11 & $8.2 \%$ & 0.11 & 0 \\
\hline Total deaths from additional neglected diseases & 28.78 & NA & 2.44 & 26.34 \\
\hline
\end{tabular}

See GBD 2013 capstone manuscript on DALYs for detail on percent (\%) change calculations (Murray et al., 2015). The estimates presented in this table are also obtainable on the website of the Institute for Health Metrics and Evaluation (IHME) and were previously published in (Vos et al., 2015; Murray et al., 2015; Abubakar et al., 2015). Information on YLDs and DALYs for Cryptosporidiosis, Cholera, and Amoebiasis is not obtainable from the website of IHME or capstone papers. Abbreviations: NA, non-applicable

and community volunteers, facilitating delivery to vast numbers of people in rural areas as well. Some individuals are not eligible to receive these drugs - children under the age of two or five years, the very sick, or pregnant women (Samuels \& Pose, 2013).

- IDM includes care for infected persons and those at risk of infection. This intervention is the prime strategy for the control of NTDs for which no preventive medicines are obtainable, such as Chagas disease, Buruli ulcer, leishmaniasis, human African trypanosomiasis, leprosy, and yaws (Samuels \& Pose, 2013).

- The use of pesticides is also needed to combat vectorborne diseases transmitted by snails, insects, or crustaceans (Samuels \& Pose, 2013).

- Management of vectors is strengthened by the provision of sanitation, hygiene, and safe water and close cooperation within sectors responsible for health, agriculture, irrigation and environment (Samuels \& Pose, 2013).

- Finally, veterinary public-health interventions are also crucial in tackling neglected tropical diseases because zoonotic diseases (e.g., anthrax, bovine tuberculosis, cysticercosis, brucellosis, echinococcosis, zoonotic trypanosomiasis, and rabies) are responsible for much of the mortality and morbidity arising from NTDs (Samuels \& Pose, 2013).

The major NTDs and intervention strategies are listed in table 4 . These strategies can control or eliminate the adversity of neglected tropical diseases by 2020 if properly implemented, although some challenges need to be overcome to achieve the goal by 2020 .

\section{ACHIEVEMENTS}

WHO has recorded incredible achievements in combating neglected tropical diseases since 2007. An estimated 1 billion people received treatment in 2015 alone. The WHO report, Integrating NTDs in global health and development, reveals how generous donations of medicines, strong political support, and improvements in living standards have guided to sustained expansion of disease control programmes in countries where these diseases are most prevalent (WHO, 2017).

Since 2007, when a group of global collaborators met to agree to tackle neglected tropical diseases, a number of international and 
Table 4: The intervention strategies of the major neglected tropical diseases, where elimination refers to elimination as a public health problem (Hollingsworth et al., 2015)

\begin{tabular}{|c|c|c|}
\hline Disease & Interventions & WHO target for 2020 \\
\hline \multicolumn{3}{|c|}{ Preventive chemotherapy (PCT) diseases, controlled by mass drug administration (MDA) programmes } \\
\hline Lymphatic filariasis (elephantiasis) & $\begin{array}{l}\text { Annual/biannual MDA (ivermectin, albendazole and DEC), vector control } \\
\text { through insecticide-treated bed nets or spraying }\end{array}$ & Global elimination \\
\hline Onchocerciasis (river blindness) & MDA (ivermectin) and vector control & Country elimination \\
\hline Schistosomiasis (bilharzia) & $\begin{array}{l}\text { MDA (praziquantel) to school-age children and high-risk adults, along with } \\
\text { WASH and possible snail control }\end{array}$ & $\begin{array}{l}\text { Regional and country } \\
\text { elimination }\end{array}$ \\
\hline $\begin{array}{l}\text { Soil-transmitted helminthiasis (roundworm, } \\
\text { whipworm, hookworm) }\end{array}$ & $\begin{array}{l}\text { MDA (albendazole, mebendazole) treatment of school-aged children. } \\
\text { Treatment of pre-school aged children and women of childbearing age is also } \\
\text { recommended }\end{array}$ & $\begin{array}{l}75 \% \text { coverage with } \\
\text { (bi) annual PCT }\end{array}$ \\
\hline Blinding trachoma & MDA (azithromycin) and surgery, along with improved hygiene & Global elimination \\
\hline \multicolumn{3}{|c|}{ Intensified disease management (IDM) diseases, controlled by increased diagnosis and management of cases } \\
\hline Chagas disease & Spraying with indoor residual insecticides, housing improvements & Regional elimination \\
\hline HAT (sleeping sickness), Gambian form & Treatment, active/mass screening and vector control with tsetse targets & Global elimination \\
\hline Leprosy & Early diagnosis and treatment & Global elimination \\
\hline $\begin{array}{l}\text { Visceral leishmaniasis (kala-azar) in the } \\
\text { Indian sub-continent }\end{array}$ & $\begin{array}{l}\text { Indoor residual spraying of insecticides, insecticide-treated bed nets, active case } \\
\text { detection, rapid diagnosis and treatment }\end{array}$ & Regional elimination \\
\hline
\end{tabular}

local partners have partnered alongside ministries of health in endemic nations to provide quality-assured medicines, and offer people with care and long-term management. In 2012, Partners endorsed a WHO NTD roadmap, contributing additional assistance and resources to eliminate 10 of the most prevalent NTDs (WHO, 2017).

Key achievements of this roadmap of the WHO NTD include (WHO, 2017):

- In 2015 alone, at least 1000 million people were treated for NTD.

- 0.556 billion individuals obtained preventive treatment for lymphatic filariasis (elephantiasis).

- More than 0.114 billion individuals received treatment for a disease caused by the filarial nematode Onchocerca volvulus (onchocerciasis, or river blindness: 62\% of those needing it).

- In 2016, only 25 human Guinea-worm disease cases were recorded, placing eradication within reach.

- HAT (sleeping sickness) cases have been lowered from 37,000 new cases in 1999 to well below 3000 in 2015.

- Trachoma - the world's top infectious cause of blindness - has been eliminated as a public health issue in Morocco, Mexico, and Oman. More than 185 million trachoma patients had surgery worldwide for trichiasis and antibiotics had been received by 56 million individuals in 2015 alone.

- Visceral leishmaniasis: $100 \%$ of Nepal's districts, $97 \%$ of Bangladesh's sub-districts, and $82 \%$ of India's sub-districts reached the elimination target in 2015.

- Only 12 confirmed human deaths were due to rabies in the WHO Region of the Americas in 2015, putting the region close to the goal of eliminating rabies in humans by 2015 .

\section{CHALLENGES}

Despite all the success achieved, NTDs remain worrying in many third-world people who is still live below the poverty line and are deprived of all the facilities necessary to lead a healthy life. WHO reports that there are still about 2.4 billion people without adequate sanitation facilities, such as toilets and latrines (Hutton et al., 2017), while more than 660 million people still drink water from "unimproved" sources such as surface water (UNICEF \& WHO, 2015). Reports also suggest that millions of people do not have access to NTD drugs, and prevention programs remain inadequately funded.

Failure to distribute drugs adequately is also a major challenge in this term. A better method of delivering and distributing drugs should need to be introduced. There are still some NTDs such as dengue fever, chikungunya which cause havoc in populations, and the recent outbreaks of zika virus and its complications create a massive concern to the associated authorities to reconsider and introduce new diagnostic tools, medicines, and insecticides to improve its control.

To overcome these challenges, strengthening joint efforts between stakeholders, along with increased support, is a prerequisite for ensuring the success of NTD programs in achieving the goal. It is now imperative to develop the best possible tools to defeat these diseases and make them accessible to workers on the ground.

\section{CONCLUSION}

The main goals of this review are to learn about the various neglected tropical diseases and how they are distributed which results in harming our socio-economic development and global economy. NTDs are more common in regions where living standards are not acceptable and where sources of pure drinking water and foods are not commonly available. Though these diseases are not considered as lethal but can lead a life to disability. Moreover, a lot of burdens are created each year by those NTDs which have a bad impact on the global economy. A must need attention is required to prevent them and basic treatments will be focused on preventive measures rather than medication. If we desire to get rid of these diseases, need to have better living conditions and ensuring of proper food and drink sources. Vector control is also a prerequisite since most NTDs are spread by vectors. Finally and foremost, what we need to do is to introduce new diagnostic tools and a better method of delivering drugs and improve the living conditions of people. 


\section{CONFLICT OF INTERESTS}

The authors declare that they have no competing interests.

\section{REFERENCES}

Abubakar, II., Tillmann, T., \& Banerjee, A. (2015). Global, regional, and national age-sex specific all-cause and cause-specific mortality for 240 causes of death, 1990-2013: a systematic analysis for the Global Burden of Disease Study 2013. The Lancet, 385(9963), 117-171. https://doi.org/10.1016/S0140-6736(14)61682-2

Byass, P., de Courten, M., Graham, W. J., Laflamme, L., McCaw-Binns, A., Sankoh, O. A., Tollman, S. M., \& Zaba, B. (2013) Reflections on the global burden of disease 2010 estimates. PLoS Medicine, 10(7), e1001477. https://doi.org/10.1371/journal.pmed.1001477

Cardona-Ospina, J. A., Villamil-Gomez, W. E., Jimenez-Canizales, C. E., Castaneda-Hernandez, D. M., \& Rodriguez-Morales, A. J. (2015). Estimating the burden of disease and the economic cost attributable to chikungunya, Colombia, 2014. Transactions of the Royal Society of Tropical Medicine and Hygiene, 109(12), 793-802. https://doi. org/10.1093/trstmh/trv094

Chen, S. H., Ravallion, M. (2008). The developing world is poorer than we thought, but no less successful in the fight against poverty. World Bank Policy Research Working Paper 4703 (WPS 4703). Retrieved from: http://documents1.worldbank.org/curated/ en/526541468262138892/pdf/NPS4703.pdf

de Vlas, S. J., Stolk, W. A., le Rutte, E. A., Hontelez, J. A., Bakker, R., Blok, D. J., Cai, R., Houweling, T. A., Kulik, M. C., Lenk, E. J., Luyendijk, M., Matthijsse, S. M., Redekop, W. K., Wagenaar, I., Jacobson, J., Nagelkerke, N. J., \& Richardus, J. H. (2016). Concerted Efforts to Control or Eliminate Neglected Tropical Diseases: How Much Health Will Be Gained?. PLoS Neglected Tropical Diseases, 10(2), e0004386. https://doi.org/10.1371/journal.pntd.0004386

Devleesschauwer, B., Havelaar, A. H., de Noordhout, C. M., Haagsma, J. A., Praet, N., Dorny, P., Duchateau, L., Torgerson, P. R., Oyen, H. V., \& Speybroeck, N. (2014). Calculating disability-adjusted life years to quantify burden of disease. International Journal of Public Health, 59(3), 565-569. https://doi.org/10.1007/s00038-014-0552-z

Herricks, J. R., Hotez, P. J., Wanga, V., Coffeng, L. E., Haagsma, J. A., Basáñez, M. G., Buckle, G., Budke, C. M., Carabin, H., Fèvre, E. M., Fürst, T., Halasa, Y. A., King, C. H., Murdoch, M. E., Ramaiah, K. D., Shepard, D. S., Stolk, W. A., Undurraga, E. A., Stanaway, J. D., Naghavi, M.,... Murray, C. (2017). The global burden of disease study 2013: What does it mean for the NTDs?. PLoS Neglected Tropical Diseases, 11(8), e0005424. https://doi.org/10.1371/journal. pntd.0005424

Hollingsworth, T. D., Adams, E. R., Anderson, R. M., Atkins, K., Bartsch, S., Basáñez, M. G., Behrend, M., Blok, D. J., Chapman, L. A., Coffeng, L., Courtenay, O., Crump, R. E., de Vlas, S. J., Dobson, A., Dyson, L., Farkas, H., Galvani, A. P., Gambhir, M., Gurarie, D., Irvine, M. A.,... NTD Modelling Consortium (2015). Quantitative analyses and modelling to support achievement of the 2020 goals for nine neglected tropical diseases. Parasites \& vectors, 8, 630. https://doi.org/10.1186/s13071015-1235-1

Hossain, M. M., Sarmiento, M. E., Acosta, \& A., Norazmi, M. N. (2017). Neglected Diseases. In: Ismail, A., Norazmi, M. N., Abdullah, J. M., Acosta, A., Sarmiento, M. E. (Eds.) Sustainable Diagnostics for Low Resource Areas. Malaysia: Penerbit Universiti Sains Malaysia, pp. 1-23.

Hotez, P. J., Alvarado, M., Basáñez, M. G., Bolliger, I., Bourne, R., Boussinesq, M., Brooker, S. J., Brown, A. S., Buckle, G., Budke, C. M., Carabin, H., Coffeng, L. E., Fèvre, E. M., Fürst, T., Halasa, Y. A., Jasrasaria, R., Johns, N. E., Keiser, J., King, C. H., Lozano, R.,... Naghavi, M. (2014). The global burden of disease study 2010: interpretation and implications for the neglected tropical diseases. PLoS Neglected Tropical Diseases, 8(7), e2865. https://doi. org/10.1371/journal.pntd.0002865

Hotez, P. J., Fenwick, A., Savioli, L., \& Molyneux, D. H. (2009). Rescuing the bottom billion through control of neglected tropical diseases. The Lancet, 373(9674), 1570-1575. https://doi.org/10.1016/S01406736(09)60233-6

Hutton, G., \& Chase, C. Water Supply, Sanitation, and Hygiene. In:
Mock, C. N., Nugent, R., Kobusingye, O., et al., editors. Injury Prevention and Environmental Health. 3rd edition. Washington (DC): The International Bank for Reconstruction and Development / The World Bank. https://doi.org/10.1596/978-1-4648-0522-6 ch9

King, C. H. (2010). Parasites and poverty: the case of schistosomiasis. Acta Tropica, 113(2), 95-104. https://doi.org/10.1016/j. actatropica.2009.11.012

Krishnamoorthy, K., Harichandrakumar, K. T., Kumari, A. K., \& Das, L. K. (2009). Burden of chikungunya in India: estimates of disability adjusted life years (DALY) lost in 2006 epidemic. Journal of Vector Borne Diseases, 46(1), 26-35.

Mavalankar, D., Tapasvi, P., Murtola, T. M., Vasan, S. (2009). Quantifying the Impact of Chikungunya and Dengue on Tourism Revenues. IIMA Working Papers, WP2009-02-03, Indian Institute of Management Ahmedabad, India Research and Publication Department.

Miguel, E., \& Kremer, M. (2004). Worms: Identifying Impacts on Education and Health in the Presence of Treatment Externalities. Econometrica, 72(1), $159-217$

Molyneux, D. (2013). Neglected tropical diseases. Community Eye Health, 26(82), 21-24.

Molyneux, D. H. (2012). The 'Neglected Tropical Diseases': Now a brand identity, responsibilities, context and promise. Parasites Vectors, 5 , 23. https://doi.org/10.1186/1756-3305-5-23

Murray, C. J., Barber, R. M., Foreman, K. J., Ozgoren, A. A., Abd-Allah, F., Abera, S. F., Aboyans, V., Abraham, J. P., Abubakar, I., Abu-Raddad, L. J., \& Abu-Rmeileh, N. M. (2015). Global, regional, and national disabilityadjusted life years (DALYs) for 306 diseases and injuries and healthy life expectancy (HALE) for 188 countries, 1990-2013: quantifying the epidemiological transition. The Lancet, 386(10009), 2145-2191. https://doi.org/10.1016/S01406736(15)61340-X

Murray, C. J., \& Acharya, A. K. (1997). Understanding DALYs (disabilityadjusted life years). Journal of Health Economics, 16(6), 703730. https://doi.org/10.1016/S0167-6296(97)00004-0

Norris, J., Adelman, C., Spantchak, Y., \& Marano, K. (2012). Social and economic impact review on neglected tropical diseases. Economic Policy/Briefing Paper. Washington DC: Hudson Institute.

Perera, M., Whitehead, M., Molyneux, D., Weerasooriya M., Gunatilleke, G. (2007). Neglected patients with a neglected disease? A qualitative study of lymphatic filariasis. PLoS Neglected Tropical Diseases, 1(2), e128. https://doi.org/10.1371/journal.pntd.0000128

Samuels, F., Pose, R. (2013). Why neglected tropical diseases matter in reducing poverty. Development Progress. Retrieved from https:// www.odi.org/sites/odi.org.uk/files/resource-documents/11520.pdf

Steinmann, P., Stone, C. M., Sutherland, C. S., Tanner, M., \& Tediosi, F. (2015). Contemporary and emerging strategies for eliminating human African trypanosomiasis due to Trypanosoma brucei gambiense: review. Tropical Medicine \& International Health, 20(6), 707-718. https://doi.org/10.1111/tmi.12483

The Lancet Global Health. (2020). Taking the neglected out of neglected tropical diseases. The Lancet Global Health, 8(2), pp. e152. https:// doi.org/10.1016/S2214-109X(19)30529-7

UNICEF and World Health Organization (WHO). (2015). Progress on Sanitation and Drinking Water - 2015 update and MDG assessment. Geneva, World Health Organization. Retrieved from https://www. who.int/water_sanitation_health/publications/jmp-2015-update/en/

Vos, T., Barber, R. M., Bell, B., Bertozzi-Villa, A., Biryukov, S., Bolliger, I. Charlson, F., Davis, A., Degenhardt, L., Dicker, D., \& Duan, L. (2015). Global, regional, and national incidence, prevalence, and years lived with disability for 301 acute and chronic diseases and injuries in 188 countries, 1990-2013: a systematic analysis for the Global Burden of Disease Study 2013. The Lancet, 386(9995), 743-800. https://doi. org/10.1016/S0140-6736(15)60692-4

Weiss, M. G. (2008). Stigma and the social burden of neglected tropical diseases. PLoS Neglected Tropical Diseases, 2(5), e237. https://doi. org/10.1371/journal.pntd.0000237

WHO (World Health Organization). (2004). The global burden of disease: 2004 update. Geneva, World Health Organization. Retrieved from https://www.who.int/healthinfo/global_burden_disease/GBD_ report 2004update full.pdf

WHO (World Health Organization). (2017). Unprecedented progress against neglected tropical diseases, WHO reports. Geneva, World Health Organization. Retrieved from https://www.who.int/news/ item/19-04-2017-unprecedented-progress-against-neglected-tropicaldiseases-who-reports 